\title{
BERJUANG MENYELAMATKAN LINGKUNGAN: GERAKAN LINGKUNGAN DI JAWA MASA KEMERDEKAAN 1950-2000
}

\author{
Nawiyanto \\ Jurusan Sejarah, Universitas Jember \\ snawiyanto@gmail.com
}

\begin{abstract}
This article discusses the environmental movement in Java during the independence era, with a special focus on the Old Order and New Order periods. Historical method was employed here in conducting the collection of source materials and synthesizing the facts into a historiographical construction. The sense of environmental crisis became the reason for continuing struggle for saving the environment. The result of discussion reveals that not only did it perform colonial lega$c y$, the movement also resulted in modifications, in terms of conservation management and movement forms. There was also a process of strengthening and broadening of the supporting groups of the movement. Especially since the 1970s, the role of non-governmental organizations and media groups intensified. This feature marked a new era that ended the dominant role of the government. In line with this process, new environmental issues were also raised and pollution was a case in point here.
\end{abstract}

Keywords: Environmental movement, environmental issues, government, non-governmental organizations, independence era, Java

\begin{abstract}
ABSTRAK
Artikel ini membahas gerakan lingkungan di Jawa pada masa kemerdekaan dengan fokus khusus periode Orde Lama dan Orde Baru. Metode sejarah digunakan dalam penggarapan dari pengumpulan sumber hingga penuangan dalam sintesis konstruksi historiografis. Keyakinan akan krisis lingkungan menjadi alasan berlanjutnya perjuangan menyelamatkan lingkungan. Hasil pembahasan menunjukkan bahwa tidak hanya warisan kolonial tetap hidup, gerakan lingkungan memperlihatkan pula adanya modifikasi dalam hal pengelolaan kawasan konservasi dan bentuk gerakan. Terdapat pula proses penguatan dan perluasan kelompokkelompok pendukung gerakan. Khususnya sejak tahun 1970-an, peranan organisasi nonpemerintah, media massa, dan kelompokkelompok akar rumput semakin menguat. Hal ini menandai sebuah era baru yang mengakhiri peranan dominan pemerintah. Seiring dengan proses ini, isu-isu baru juga dibangun dan pencemaran merupakan ilustrasi pokok di sini.
\end{abstract}

Kata kunci: gerakan lingkungan, isu lingkungan, pemerintah, organisasi non-pemerintah, masa kemerdekaan, Jawa

\section{PENDAHULUAN}

Jawa menempati posisi sentral dalam gerakan lingkungan di Indonesia pada masa kemerdekaan. Sebanyak 54\% protes lingkungan yang terjadi di Indonesia pada masa Orde Baru hingga Orde Reformasi terdapat di Pulau Jawa. Persentase ini jauh lebih besar apabila dibandingkan dengan persentase kejadian protes lingkungan yang berlang- sung di Sumatera sebesar 22\%, dan di Kalimantan sebesar 9 . Secara kuantitatif, peristiwa protes lingkungan di Jawa pada periode tersebut dilaporkan mencapai 284 kasus, sedangkan di Sumatera sebanyak 109 kasus, dan di Kalimantan sebanyak 42 kasus (Situmorang, 2013:141). Kejadian protes lingkungan yang terjadi di Jawa tampak begitu menonjol proporsi dan frekuensinya, sangat kontras manakala ditempatkan 
dalam konteks komparasi proporsi wilayah daratan Pulau Jawa, yang hanya menyusun sekitar $7 \%$ dari seluruh luas permukaan tanah Indonesia.

Posisi sentral Jawa dalam gerakan lingkungan di Indonesia merupakan produk kombinasi beragam faktor. Secara demografis Jawa merupakan pulau terpadat penduduk di Indonesia. Meskipun proporsi penduduk Jawa terus menurun, dari $70 \%$ dari total penduduk jawa pada tahun 1930 (Furnivall, 1939:347), menjadi $60 \%$ pada tahun 1990. Akan tetapi, secara absolut penduduk yang bermukim di Jawa terus saja meningkat. Pada tahun 1990 penduduk Jawa telah mencapai 108 juta jiwa (Van der Eng, 1996:279). Faktor demografis ini bergabung dengan dengan kedudukan Jawa sebagai pusat kekuasaan dan tempat yang mengalami pertumbuhan pesat. Penerapan revolusi hijau di pedesaan Jawa yang padat input kimiawi, serta perkembangan sektor industri di wilayah perkotaan sejak era Orde Baru, membawa perubahan dan berdampak radikal bagi lingkungan di Jawa.

Berbarengan dengan perkembangan tersebut, problem lingkungan di Jawa semakin menumpuk dan mengarah pada krisis lingkungan. Keadaan ini membangkitkan keprihatinan berbagai pihak dan mendorong dilancarkanya gerakan protes lingkungan. Dilihat dari persebaran lokasi kejadian berdasarkan wilayah provinsi, Daerah Khusus Ibukota (DKI) Jakarta menempati posisi teratas dalam jumlah kejadian protes lingkungan. Posisi Jakarta disusul oleh Provinsi Jawa Barat pada posisi kedua, posisi berikutnya ditempati oleh Jawa Tengah, dan Jawa Timur (Situmorang, 2013:137-140).

Kontras dengan banyaknya peristiwa protes lingkungan di Jawa masa kemerdekaan, belum banyak kajian yang dihasilkan untuk membahas perkembangan gerakan lingkungan secara historis. Kajian Situmorang (2013), sama sekali tidak menyinggung gerakan protes lingkungan sebelum era Orde Baru dan masa kolonial. Sementara itu, beberapa kajian akademis yang sudah ada (Boomgaard, 1999; Nawiyanto, 2013) membatasi pembahasaannya pada era kolonial. Kedua fenomena tersebut memunculkan impresi bahwa ada keterputusan sejarah dalam gerakan lingkungan. Kajian tentang dekolonisasi ekonomi Indonesia yang dilakukan Lindblad (2011) memperlihatkan kesukaran serius untuk menarik garis demarkasi yang tegas antara masa kolonial dengan masa kemerdekaan, tidak seperti dekolonisasi politik yang jelas batasnya.

Sementara itu, beberapa kajian lain cenderung masih bersifat parsialistik. Kajian Tim Presidium Kelompok Pelestari Sumberdaya Alam (1997) melahirkan impresi bahwa gerakan lingkungan terbatas pada kegiatan peyelamatan lahan kritis melalui kegiatan penghijauan dan reboisasi yang disponsori oleh negara. Keterlibatan pelaku di luar negara belum terungkap secara memadai. Kesan parsialistik juga muncul lewat kajian Lucas dan Djati (2000) yang membahas politik pencemaran di Kali Surabaya. Sebagai studi kasus, harus diakui bahwa kajian ini memberi gambaran yang sangat kaya mengenai dinamika politik pencemaran di tingkat lokal dengan mengungkap peran pemerintah, perusahaan swasta, media massa, aktivis lingkungan, dan korban pencemaran. Akan tetapi, lingkupnya yang lokalistik dengan sendirinya juga menciptakan keterbatasan untuk memahami posisi gerakan anti pencemaran dalam konteks perkembangan historis gerakan lingkungan dalam lingkup spasial yang lebih luas, serta lingkup temporal yang lebih panjang.

Oleh karena itu, tulisan ini hen- 
dak melihat lebih jauh implikasi dari pandangan yang mengakui tiadanya batas-batas yang jelas antara periode kolonial dan periode kemerdekaan dalam konteks yang berbeda, yakni dalam konteks gerakan lingkungan. Kalau sejarah dipandang sebagai proses pengulangan dan pembaharuan, maka menarik untuk dilihat aspek-aspek gerakan lingkungan pada masa kemerdekaan yang menampilkan baik kontinuitas maupun diskontinuitas sejarah. Secara lebih spesifik artikel ini bertujuan: (1) Mengkaji warisan yang ditinggalkan gerakan lingkungan kolonial di Jawa dan berbagai modifikasinya; (2) Memaparkan perkembangan isu dan bentuk gerakan yang muncul di Jawa, serta (3) Menjelaskan upaya esksponen gerakan lingkungan dalam memperkuat gerakannya.

Secara teoretis, gerakan lingkungan tergolong sebagai gerakan sosial baru. Kebaruan gerakan sosial baru dibanding gerakan sosial lama terletak di antaranya pada basis dukungannya yang melintasi sekat-sekat kelas. Dengan karakteristik ini, gerakan sosial baru bukan manifestasi perjuangan kelas atau gerakan kelas, dan fokusnya bersifat non-material (Singh, 2002:1920). Sebagai gerakan sosial baru, gerakan lingkungan merupakan upaya kolektif untuk menciptakan tatanan yang lebih berkeadilan terhadap lingkungan (Situmorang, 2013:12). Menurut Morrison, gerakan lingkungan terdiri atas tiga bentuk, yakni gerakan lingkungan sukarela, gerakan lingkungan publik, dan gerakan lingkungan institusional (Aditjondro, 2003:164-165).

Dalam pandangan Habermas, gerakan lingkungan merupakan tanggapan atas krisis lingkungan yang mengancam kehidupan akibat lepasnya kendali nilai-nilai moral (Zid, 2009:913). Kesadaran akan krisis merupakan hasil pembacaan atas problem objektif yang sering bersifat teknis oleh agens yang kemudian mentransformasikannya menjadi isu-isu politik di ranah publik dengan tujuan mencari solusi. Agens yang berperan sebagai "pengubah" ini berasal dari berbagai kalangan, termasuk di antaranya ilmuwan, media, dan kelompok aktivis lingkungan (Garner, 1996:8). Hannigan (2006:63-75) menyebut kelompok semacam ini sebagai "pembuat klaim" yang kemudian mendesakkan kebenaran klaim mereka atas "kegawatan" problem dan urgensi respons politik untuk mengatasinya.

Kajian tentang gerakan lingkungan pada masa kemerdekaan dipandang penting untuk memperkaya wawasan sejarah mengenai periode ini, khususnya masa Orde Lama dan Orde Baru. Historiografi Indonesia periode kemerdekaan memperlihatkan tekanan yang kuat pada dimensi ekonomi, sosial dan politik. Historiografi lingkungan relatif masih lemah dan belum berkembang. Keadaan demikian perlu diatasi demi terwujudnya historiografi yang lebih utuh. Historiografi lingkungan menjanjikan kemampuan merelevansikan kajian historis dengan "kebutuhan dan kepentingan sekarang" seperti disuarakan Becker dan Beard melalui sudut pandang kekinian (Ankersmith, 1987:330). Dengan merujuk pada perspektif Voltaire yang menekankan utilitarianisme dalam melihat masa silam (Mazlish, 1966:68), historiografi lingkungan khususnya gerakan lingkungan menawarkan nilai kemanfaatan yang besar.

Dari sudut pandang praktis, kajian historis gerakan lingkungan masa kemerdekaan dapat dijadikan acuan dan reservoir kearifan sejarah bagi pemerintah, aktivis lingkungan, dan elemen-elemen masyarakat dalam memperjuangkan perlindungan lingkungan. Kajian-kajian tersebut dapat 
dijadikan pijakan dalam rangka memperkuat gerakan lingkungan, dari aspek jaringan organisasi, basis material dan massa pendukung, sehingga tercipta kekuatan kolektif yang memadai untuk mewujudkan lingkungan yang lestari. Kajian-kajian tentang gerakan lingkungan pada masa kemerdekaan dapat mengantarkan pada kesadaran tentang tanggung jawab diri sebagai bangsa merdeka terhadap lingkungan yang menopang dan mendasari eksistensinya, bukan hanya tanggung-jawab diri sebagai bangsa secara politis untuk membangun masyarakat sejahtera dan bermartabat, sejajar dengan bangsa lain dalam pergaulan internasional.

\section{METODE PENELITIAN}

Sebagai riset sejarah, penelitian tentang gerakan lingkungan di Jawa pada masa kemerdekaan ini menggunakan metode sejarah dalam penggarapannya. Salah satu karakter utama riset sejarah adalah penggunaan perspektif diakronis dalam membangun penjelasan atas subyek yang dikaji, artinya memanjang secara temporal, namun dengan batasan geografis yang jelas (Kuntowijoyo, 2008). Secara umum riset sejarah meliputi empat tahapan kerja, yakni (1) pengumpulan sumber sejarah yang relevan dengan tema yang digarap, (2) penyikapan sumber secara kritis untuk menetapkan otentisitas (kritik eksternal) dan pengujian informasi dari sumber-sumber dimaksud untuk memperoleh informasi yang kredibel sebagai fakta-fakta sejarah (kritik internal), (3) penafsiran faktafakta sejarah untuk dijadikan argumentasi historis, dan (4) penuangkan argumentasi dalam bentuk sintesis historiografis (Storey, 2011; Gottschalk, 1986).

Untuk kepentingan riset ini sumber sejarah yang dipakai meliputi sum- ber primer dan sumber sekunder. Sumber primer yang digunakan di sini berupa terbitan sejaman, diantaranya Rimba Indonesia, Gema Perhutani, Menara Perkebunan, Majalah Penggemar Alam. Bahanbahan ini diperoleh dari berbagai lembaga, di antaranya Perpustakaan Nasional Republik Indonesia (Jakarta), Perpustakaan Daerah Istimewa Yogyakarta (Malioboro), Perpustakaan Fakultas Kehutanan Universitas Gadjah Mada, (Yogyakarta), dan Perpustakaan Departemen Pertanian (Bogor). Sumber sekunder yang digunakan dalam penelitian ini meliputi berbagai buku, artikel, laporan hasil penelitian baik yang sudah terbit maupun belum, serta bahan-bahan lain yang memuat informasi yang relevan dengan riset ini. Sumber sekunder dilacak di berbagai tempat di Jakarta, khususnya Perpustakaan Nasional Republik Indonesia Indonesia (PNRI) dan Perpustakaan Wahana Lingkungan Hidup Indonesia (Walhi). Sebagaian sumber penulisan didapat dari berbagai perpustakaan di Yogyakarta seperti perpustakaan di lingkungan Universitas Gadjah Mada khususnya Fakultas Kehutanan, serta di Perpustakaan Kolese Santo Ignatius Kotabaru.

\section{HASIL DAN PEMBAHASAN}

\section{Warisan Kolonial Dan Modifikasinya}

Gerakan lingkungan di Jawa mempunyai akar sejarah pada masa kolonial terutama sejak paruh kedua abad ke-19. Gerakan lingkungan di Jawa masa kolonial memperlihatkan adanya beberapa karakteristik pokok. Pertama, gerakan ini muncul erat kaitannya dengan kepentingan pertanian kolonial khususnya sektor perkebunan yang menjadi fondasi ekonomi kolonial. Keberlangsungan sektor perkebunan 
mengharuskan pemertahanan kawasan hutan dan penyelamatan kawasan hutan yang terlanjur rusak khususnya di daerah pegunungan untuk menjamin terjaganya tata air baik pada musim penghujan maupun musim kemarau, serta perlindungan dari bahaya erosi yang menurunkan produktivitas pertanian-perkebunan.

Kedua, gerakan lingkungan masa kolonial juga menaruh perhatian pada perlindungan elemen-elemen lingkungan baik flora, fauna, maupun situs alam yang bernilai eksotis, estetis, dan ilmiah sebagai kekayaan keragaman hayati yang harus diselamatkan kehancuran akibat tekanan komersialisasi. Ketiga, gerakan lingkungan kolonial memperlihatkan peran negara yang dominan dalam pengelolaan proyekproyek konservasi, inisiatif pembentukan berasal dari kelompok aktivis perlindungan alam, yakni Perhimpunan Hindia Belanda untuk Perlindungan Alam yang didirikan pada tahun 1912 Meskipun cenderung menonjol sifat elitisnya, gerakan lingkungan di Jawa masa kolonial menorehkan sejumlah capaian penting, di antaranya adalah pembentukan proyek konservasi berupa cagar alam maupun suaka margasatwa, peletakan kerangka hukum perlindungan satwa fauna dan flora, kegiatan perburuan, serta yang tidak kalah pentingnya adalah terbentuknya organ birokrasi yang secara khusus menangani kegiataan konservasi lingkungan (Nawiyanto, 2014: 43-44).

Gerakan lingkungan di Jawa pada masa kemerdekaan memperlihatkan beberapa warisan dari gerakan lingkungan masa kolonial. Warisan kolonial tersebut menjadi elemen yang membentuk kesinambungan sejarah antara gerakan lingkungan masa kolonial dan gerakan lingkungan masa kemerdekaan. Keberadaan situs-situs konservasi lingkungan dan program gerakan lingkungan menjadi wujud konkret warisan tersebut. Gerakan lingkungan kolonial meninggalkan 61 situs konservasi, berupa cagar alam dan suaka margasatwa di Jawa, baik dalam ukuran besar maupun kecil. Situs-situs konservasi warisan kolonial berlokasi secara tersebar, mulai dari ujung barat hingga ujung timur Jawa, dengan rincian: 3 di Banten, 1 di Batavia, 10 di Bogor, 10 di Priangan, 6 di Pekalongan, 4 di Semarang, 1 di Rembang, 2 di Banyumas, 1 di Kedu, 1 di Bojonegoro, 3 di Madiun, 2 di Kediri, 5 di Malang, 1 di Madura, dan 10 di Besuki (Endert, 1936: 181-183). Warisan utama lainnya yang ditinggalkan adalah adopsi program penghijauan dan reboisasi sebagai panasea utama untuk mengatasi permasalahan lingkungan khususnya problem erosi, lahan kritis, dan hutan gundul, yang dipandang membahayakan Jawa sebagai sentra pertanian dan perkebunan, serta mengancam kemakmuran penduduk.

Tetap bertahannya warisan kolonial pada masa kemerdekaan disebabkan setidaknya oleh dua alasan pokok. Pertama, tidak dipungkiri bahwa para aktivis gerakan lingkungan pada masa kemerdekaan, khususnya pada dekade awal setelah proklamasi, adalah orangorang yang pernah terlibat secara aktif dalam gerakan lingkungan pada masa kolonial. Sebagian di antara mereka adalah orang-orang Belanda (Barat) yang tetap tinggal atau terus bekerja di Indonesia, baik pada instansi pemerintah, pusat riset milik pemerintah dan swasta, maupun perkebunan. Sebagian lainnya adalah orangorang pribumi Indonesia yang pernah bekerja pada instansi pemerintah kolonial terutama Jawatan Kehutanan. Para aktivis gerakan lingkungan tersebut sejatinya adalah orang-orang yang sejak masa kolonial memang telah bekerja pada instansi yang berurusan dengan 
masalah lingkungan atau secara personal tertarik pada isu lingkungan. Secara politik zaman telah berubah, era kolonial digantikan era kemerdekaan, namun mereka tetap mempertahankan minat pada hal yang sama, yakni perlindungan berbagai aspek lingkungan dari krisis yang membahayakan.

Alasan kedua bagi berlakunya kesinambungan sejarah adalah fakta bahwa persoalan yang dihadapi gerakan lingkungan, terutama pada dekade-dekade awal kemerdekaan, secara esensial tidak banyak mengalami perubahan. Seperti halnya pada masa kolonial, gerakan lingkungan di Jawa pada masa kemerdekaan dihadapkan pada permasalahan kronis berupa kerusakan lingkungan hutan, erosi dan tanah kritis, serta perburuan satwa liar secara illegal. Kalaupun terdapat perbedaan di antara kedua zaman, perbedaan yang pokok lebih berkaitan dengan magnitudo atau skala problem lingkungan, ketimbang dalam segi kebaruan isu lingkungan yang mereka hadapi. Permasalahan lingkungan pada masa kemerdekaan diyakini jauh lebih parah dan masif skalanya dibandingkan dengan masa kolonial.

Mereka yang berada dalam birokrasi pemerintah, khususnya Jawatan Kehutanan dan Jawatan Pertanian, termasuk di antara pihak pertama yang meyakini gawatnya situasi. Mereka merasakan adanya krisis dan terpanggil membunyikan alarm untuk memperingatkan khalayak yang lebih luas bahwa telah terjadi krisis akibat erosi dan rusaknya hutan. Terbentuknya kesadaran akan krisis terbaca dalam tulisan-tulisan yang mereka publikasikan pada tahun 1950-an. Kepala Jawatan Pertanian Rakyat, Soeprapto (1954:331) memperingatkan bahwa puluhan ribu hektar tanah di daerah Surakarta telah hancur dan menjadi tandus akibat erosi. Sebelumnya, Menteri
Pertanian Moh. Sardjan (1953:38) juga telah memberi ilustrasi yang lebih menakutkan tentang sejumlah negeri yang hancur akibat bencana erosi. Demikian pula, Ponto (1954:323) menggarisbawahi bahwa bencana akibat erosi jauh lebih besar ketimbang politik. Kesadaran akan situasi krisis mendorong pencarian solusi dan formulasi kebijakan untuk memecahkannya. Perlu disebut pula, A. Hoogerwerf, Kepala Bagian Perlindungan Alam dan Pemburuan Kebun Raya Bogor, memperingatkan mengeringnya mata air, keruhnya air sungai, ancaman punahnya satwa liar yang tengah berlangsung (Hoogerwerf, 1953:285,292).

Keyakinan subjektif sejumlah aktivis lingkungan mengenai situasi krisis memang mempunyai landasan faktual. Tekanan demografis atas lingkungan di Jawa memang bertambah berat dengan tumbuh pesatnya penduduk. Penduduk Jawa terus meningkat dengan berakhirnya pendudukan Jepang dan perang revolusi kemerdekaan. Keadaan yang lebih stabil menciptakan kondisi yang kondusif bagi pertumbuhan penduduk Jawa. Untuk sekedar gambaran, data statistik mengindikasikan bahwa penduduk Jawa meningkat dari 48 juta pada tahun 1945 menjadi 56 juta pada tahun 1955, dan 68 juta pada tahun 1965. Pada tahun 1975 penduduk Jawa berjumlah sekitar 82 juta dan menjadi sekitar 100 juta pada tahun 1985 (Van der Eng, 1996:277-279). Peningkatan jumlah penduduk Jawa semakin menekan daya dukung lingkungan dalam menopang kebutuhan hidup penduduk yang tinggal di dalamnya.

Membesarnya persoalan lingkungan yang dihadapi khususnya pada dekade-dekade awal kemerdekaan juga disebabkan oleh faktor sosio-politis. Perubahan tatanan politik dari negara kolonial ke negara merdeka, yang berlangsung melalui transisi pendudukan 
militer Jepang dan revolusi kemerdekaan, telah dibarengi dengan meluasnya kerusakan lingkungan khususnya hutan. Pada masa pendudukan militer Jepang pembabatan hutan terjadi secara besar-besaran, tidak terkecuali di kawasan hutan lindung.

Orientasi Jepang pada pelipatgandaan hasil hutan untuk mendukung kepentingan perang membuat kegiatan terpenting yang dilakukannya adalah penebangan. Untuk menutup besarnya kebutuhan, penebangan terus dilakukan meskipun di luar rencana, sedangkan pemeliharaan dan penanaman kembali tanaman hutan sama sekali tidak dipedulikan. Banyak pohon yang masih berusia muda di sepanjang jalan dan rel kereta api, misalnya di Cikampek Selatan, ditebang habis. Penebangan liar terjadi di tempat lain seperti daerah hutan Pemalang, Balapulang, Gundih, Cepu, Parengan, Madiun, dan Blitar (Poerwokoesoemo, 1950:20, 1974:11).

Sepanjang tahun 1943 dan 1944 permintaan kayu meningkat dua kali lipat. Permintaan kayu perkakas, kayu bakar dan arang sangat besar karena bahan-bahan ini diperlukan untuk memenuhi kebutuhan bahan bakar kereta api dan berbagai macam industri seperti semen, spiritus, korek api (Peluso, 1992:95). Kayu hutan yang penting termasuk di antaranya rasamala yang baik untuk perkakas dan jamuju di hutan Jawa Barat untuk dibuat tong-tong pengepakan bahan pangan untuk tentara Jepang seperti kecap dan sayurmayur. Demikian juga, permintaan dari pihak militer Jepang akan produk kayu juga banyak karena diperlukan untuk bagian-bagian perlengkapan militer dan bangunan kubu-kubu pertahanan (Fernandes, 1946:57). Di lereng Argopura pohon-pohon Jamuju ditebang untuk memenuhi permintaan pabrik korek api, Machi Kozo dan Mokozo di Suraba- ya. Hal yang sama terjadi pada pohonpohon jamuju di daerah hutan Brantas Timur (Poerwokoesoemo, 1974:14).

Kerusakan hutan pada periode pendudukan Jepang juga disebabkan oleh kebijakan Jepang dalam bidang pertanahan yang diorientasikan pada pelipatgandaan produksi bahan pangan. Oleh para residen Jepang kawasan hutan dipinjamkan kepada rakyat, untuk selanjutnya dikonversi menjadi lahan pertanian. Kebijakan demikian dijumpai di berbagai tempat di Jawa dengan total area yang dipinjamkan seluas 4.428 hektar dan melibatkan sebanyak 8.242 orang. Rinciannya adalah 2.501 hektar di Wilayah Inspeksi I Bandung diberikan kepada 4.928 orang, 225 hektar di Wilayah Inspeksi II Yogyakarta diserahkan kepada 725 orang, 340 hektar di Wilayah Inspeksi III Semarang diberikan kepada 928 orang, 819 hektar di Wilayah Inspeksi IV Surabaya diberikan kepada 1.521 orang, dan 543 hektar di Wilayah Inspeksi V Malang dipinjamkan kepada 86 orang (Poerwokoesoemo, 1974:25-26). Konversi dan peminjaman lahan hutan yang dilakukan Jepang di berbagai tempat di Jawa telah menimbulkan berbagai kerusakan lingkungan hutan.

Pada masa kemerdekaan lahan hutan yang telah dibuka dan diduduki penduduk tidak jarang kemudian diklaim sebagai milik individu. Hal ini dilegitimasi dengan penafsiran bahwa kemerdekaan berarti bebas dari aturan apapun yang mengikat, khususnya hukum kolonial yang dianggap telah membatasi akses orang-orang pribumi terhadap sumberdaya hutan. Penafsiran ini juga membawa implikasi adanya kebebasan untuk mengambil tindakan apa saja termasuk yang bersifat destruktif terhadap lingkungan, yang sebelumnya telah dilindungi dan dinyatakan sebagai area konservasi berdasar hukum kolonial (Poerwokoesoemo, 
1954:38). Tidak mengherankan, selama revolusi kemerdekaan kerusakan hutan di Jawa justru bertambah parah. Seorang rimbawan menyatakan bahwa penggundulan hutan telah memuncak sejak revolusi (Soedarma, 1959b:79).

Kerusakan hutan pada periode ini untuk seluruh Jawa ditaksir mencapai luas 537.700 hektar pada tahun 1950 dan meningkat menjadi 545.300 pada tahun berikutnya (Soedarma, 1959a:45). Penggundulan hutan dapat dipastikan tidak berhenti pada dekade tahun 1950an dan 1960-an, sebaliknya justru terus berlanjut dan bahkan mengalami eskalasi di berbagai tempat. Sebagai ilustrasi, di salah satu wilayah yang paling luas area hutannya di Jawa, yakni wilayah Karesidenan Besuki, hutan yang gundul mencapai 30.000 hektar pada tahun 1969, artinya bertambah luas dibanding area hutan gundul pada tahun 1960 yang mencapai angka 20,200 hektar (Perusahaan Kehutanan, 1969:10). Proporsi hutan di Jawa pun sudah jauh dari ideal untuk berfungsi menjaga tata hidrologis, klimatologis, dan orologis karena tinggal 22 persen saja, padahal secara ideal minimal 44 persen (Soedarma, 1959b:78).

Dengan persoalan yang secara esensial relatif sama, kecuali skala dan tingkat keparahannya, kesinambungan historis pun muncul dalam program gerakan untuk merespons persoalan yang menghadang. Penghijauan dan reboisasi, yang telah diterapkan pada masa kolonial, dilanjutkan adopsinya pada masa kemerdekaan dan keduanya dianggap sebagai panasea atas kerusakan tanah dan lingkungan hutan. Peluncuran program penghijauan dan reboisasi didahului dengan sebuah maklumat yang dikeluarkan oleh pemerintah pusat pada akhir 1951. Maklumat ini menjadi momen ditabuhnya genderang yang menandai dimulainya "perang tanpa ampun" ter- hadap erosi dan lahan gundul (Sardjan, 1953:54). Senjata yang digunakan dalam perang ini tidak lain adalah warisan kolonial.

Dalam perkembangannya, modifikasi memang dilakukan. Menimba pelajaran dari pengalaman Jepang dan Amerika Serikat, serta menimbang eskalasi problem erosi dan lahan kritis, serta ditambah lagi dengan merebaknya bencana banjir yang semakin parah akibat meluasnya kerusakan hutan, pelaksanaan penghijauan dan reboisasi pun diperbaiki berdasar rekomendasi baik dari berbagai ahli maupun Kongres Kehutanan Indonesia Pertama tahun 1955. Perbaikan dilakukan dengan pelibatan dukungan massa rakyat, perluasan lingkup kegiatan menjadi berskala nasional, serta pelaksanaan program secara lebih teratur, dan pemberian peran kepada pemerintah sebagai motor utama gerakan. Dari perbaikan inilah kemudian lahir Program Penghijauan Nasional (PPN) pada era Orde Lama. PPN dilaksanakan untuk kali pertama pada tahun 1961 dan oleh Pemerintah Orde Baru program ini ditingkatkan frekuensi pelaksanaannya menjadi kegiatan rutin tahunan (Tim Presidium, 1997:44-45, 104-105).

Selain dari sisi lingkup dan regularitas pelaksanaan, modifikasi program penghijauan dan reboisasi dilakukan pada sisi kelembagaan. Berbeda dengan masa kolonial dan awal pelaksanaan pada tahun 1950-an yang lebih berbasis pada kepanitiaan ad hoc, PPN diselenggarakan secara lebih terlembaga dan terstruktur melalui jalur birokrasi pemerintah. Komando tertinggi program dipegang oleh Menteri Pertanian yang membawahkan Biro Penyelamatan Tanah dan Air, yang diberi tanggung jawab dalam pelaksanaan kegiatan penghijauan dan reboisasi setiap tahunnya, selain ditugasi mengumpulkan data kerusakan hutan dan lahan. 
Sejak tahun 1967 penghijauan dan reboisasi diserahkan pelaksanaannya pada dua instansi berbeda. Penghijauan diserahkan kepada Direktorat Penggunaan Tanah, sedangkan reboisasi menjadi tanggung-jawab Direktorat Pembinaan Hutan. Kedua instansi berada dalam naungan Direktorat Jenderal Kehutanan (Tim Presidium, 1997:16-20).

Dalam pelaksanaan kegiatan dari tahun ke tahun, perbaikan dari segi kelembagaan program penghijauan dan reboisasi sering diupayakan. Sejak tahun 1976 penyelenggaraan PPN diserahkan kepada pemerintah daerah dengan maksud lebih mengefektifkan pelaksanaanya. Dengan perubahan ini, instansi di tingkat pusat tugasnya lebih difokuskan pada aspek perencanaan, bimbingan teknis dan penggunaan anggaran. Instansi di tingkat pusat yang terlibat dalam kegiatan bersifat antardepartemental, meliputi Departmen Pertanian, Departemen Dalam Negeri, Departemen Pekerjaan Umum, Bappenas dan Kantor Menteri Negara Lingkungan Hidup. Sebelum perubahan tersebut, kegiatan penghijauan dan reboisasi dilaksanakan melalui proyekproyek Departemen Pertanian dengan sumber dana APBN. Sejak tahun 1976 kegiatan penghijauan dan reboisasi diselenggarakan melalui program bantuan Instruksi Presiden (Inpres). Seiring dengan pembentukan Departemen Kehutanan sebagai departemen tersendiri pada tahun 1983, tanggung-jawab program penghijauan dan reboisasi dialihkan kepada Direktorat Jenderal Reboisasi dan Rehabilitasi Lahan (Tim Presidium, 1997:18-30).

Warisan kolonial berupa situssitus area konservasi juga mengalami modifikasi pada masa kemerdekaan. Modifikasi terpenting adalah diubahnya beberapa situs konservasi menjadi taman nasional. Menurut Pasal 1 ayat 14 Undang-Undang Republik Indonesia No. 5 Tahun 1990 tentang Konservasi Sumber Daya Alam Hayati dan Ekosistemnya, Taman Nasional diartikan sebagai "kawasan pelestarian alam yang mempunyai ekosistem asli, dikelola dengan sistem zonasi yang dimanfaatkan untuk tujuan penelitian, ilmu pengetahuan, pendidikan, menunjang budidaya, pariwisata, dan rekreasi". Pembentukan taman nasional didasari pertimbangan mengharmoniskan kepentingan perlindungan dengan kepentingan pengembangan demi menunjang kegiatan pendidikan, penelitian, dan rekreasi (Sumarwoto, 2004:145-146).

Penetapan secara formal beberapa situs konservasi sebagai taman nasional tidak terjadi tiba-tiba. Beberapa perkembangan mendahuluinya. Pada tahun 1968 disebutkan bahwa beberapa kawasan konservasi di Jawa mulai dibuka untuk kepentingan turisme, yakni Telagawarna, Sukawajana, Gunung Gede, Telaga Patengan, PangandaranPenanjung, Laut Pasir Tengger, dan Baluran, sedangkan Hutan Betiri untuk kegiatan berburu (Nasution, 1968:22). Sebagian situs lama warisan Belanda diperluas. Perluasan area yang penting misalnya terjadi pada Cagar Alam dan Suaka Margasatwa Ujung Kulon melalui pembentukan zona penyangga dengan menambahkan area hutan Gunung Honje seluas 10.000 hektar. Tujuannya adalah untuk mengamankan kelangsungan hidup badak bercula satu (Rhinocerus sundaicus) (Nasution, 1968:21).

Pada tahun 1982 Menteri Pertanian, Ir. Soedarsono Hadisapoetro, mendeklarasikan pembentukan tamantaman nasional di Indonesia dalam Kongres Taman Nasional Sedunia ke III di Bali. Kawasan yang direncanakan sebagai calon taman nasional dituangkan dalam SK Menteri Pertanian 
Republik Indonesia Nomor 736/ Mentan/X/1982 tanggal 14 Oktober 1982. Perlu waktu sepuluh tahun untuk mulai merealisasikan perubahan caloncalon kawasan taman nasional menjadi taman nasional. Penetapannya secara formal dituangkan melalui keputusan menteri kehutanan, setelah terbentuknya kembali Departemen Kehutanan dalam kabinet pemerintahan sejak tahun 1983. Secara bertahap keberadaan taman nasional mulai muncul pada tahun 1992 dan hingga keptuusan yang dikeluarkan pada tahun 2004 telah terbentuk 12 taman nasional di Jawa. Keduabelas taman nasional tersebut yakni Ujung Kulon, Kepulauan Seribu, Gunung Halimun, Gunung GedePangranggo, Karimunjawa, BromoTengger-Semeru, Meru Betiri, Baluran, Alas Purwo, Merapi, Merbabu, dan Ciremai.

Selain modifikasi status dari cagar alam atau suaka margasatwa menjadi taman nasional, pada masa kemerdekaan terjadi pula penambahan jumlah situs konservasi. Dari sebanyak 61 situs konservasi yang diwarisi pada masa kolonial Belanda meningkat menjadi 68 buah pada tahun 1968 (Nasution, 1968:21). Termasuk situs konservasi baru yang ditambahkan di antaranya adalah Telagawarna (Bogor), Janlappa (Bogor), Bawean, dan Dataran Tinggi Hyang (Besuki). Baik fenomena penambahan situs maupun modifikasi status merupakan capaian nyata gerakan lingkungan pada masa kemerdekaan. Capaian lain yang tidak kalah pentingnya adalah pemunculan isu baru dan program baru dalam gerakan lingkungan, yang dibahas dalam bagian berikut.

\section{Memformulasi Isu dan Program Baru}

Meskipun sudah muncul sejak masa kolonial (Nagtegaal, 1995), prob- lem polusi atau pencemaran mulai banyak menarik perhatian dan menjadi isu hangat dalam gerakan lingkungan di Jawa baru sejak sekitar tahun 1970an. Menghangatnya isu pencemaran di ranah publik menandakan bahwa problem pencemaran telah mulai membelit Jawa, sebagai dampak negatif perkembangan industri yang mulai marak beroperasi di wilayah perkotaan. Terlepas dari kontribusi yang diberikan dalam bentuk penyerapan tenaga kerja dan sumber pendapatan baik bagi pemerintah maupun masyarakat, kegiatan-kegiatan di sektor industri yang mulai banyak berkembang khususnya di kota-kota besar di Jawa di bawah pemerintahan Orde Baru juga menyebabkan terjadinya pencemaran lingkungan (Lucas dan Djati, 2000:ii). Limbah industri yang dibuang begitu saja tanpa melalui proses pengolahan telah memasukkan partikel-partikel beracunnya ke dalam lingkungan dan mengancam kehidupan.

Dijadikannya isu pencemaran sebagai agenda dan fokus gerakan tidak terpisah dari peran Kelompok Sepuluh dan Wahana Lingkungan Hidup Indonesia (WALHI) sebagai motornya. Agenda baru tersebut diangkat secara publik bersamaan dengan peringatan Hari Lingkungan 1978 (Aditjondro, 2003:129). Dengan diangkatnya isu pencemaran sebagai agenda gerakan, maka terjadi pula identifikasi pihakpihak yang menjadi target dan musuh gerakan. Pihak-pihak yang membuang limbah dan mencemari lingkungan, baik korporasi maupun individual, dipandang sebagai musuh gerakan. Perhatian terhadap isu pencemaran semakin menguat dengan munculnya Kelompok Studi Pencemaran Lingkungan terbentuk pada tahun 1980 (Aditjondro, 2003:131). Sesuai dengan namanya, kelompok ini hadir sebagai kelompok yang menarauh perhatian secara khu- 
sus pada masalah pencemaran dan dampaknya bagi masyarakat dan lingkungan.

Agenda gerakan dalam memerangi pencemaran disimbolisasi dengan diangkatnya dua kasus pencemaran. Satu kasus terkait dengan pencemaran oleh Pabrik Kimia, Diamond, yang berlokasi di Semarang. Kasus yang kedua adalah potensi atau resiko munculnya pencemaran yang bersumber dari Pembangkit Tenaga Nuklir yang direncanakan akan didirikan di dekat Rembang Jawa Tengah (Aditjondro, 2003:130). Minat dan perhatian terhadap isu pencemaran sebagai agenda gerakan lingkungan semakin menguat dengan terjadinya dua insiden terkait dengan pencemaran. Insiden pertama adalah bocornya laporan rahasia BATAN yang sampai pada Kantor Berita Antara tentang tingginya kadar merkuri di perairan Teluk Jakarta. Tersebarnya informasi tersebut ke wilayah publik mendorong Kelompok Sepuluh melakukan observasi lapangan dan serangkaian uji laboratorium atas sampel air laut untuk memastikan kadar pencemaran merkuri. Uji kesehatan atas warga nelayan Teluk Jakarta mengindikasikan bahwa mereka telah mengidap penyakit minamata akibat terkontaminasi merkuri (Aditjondro, 2003:130-131). Insiden kedua yang ikut mendorong minat terhadap isu pencemaran adalah serbuan para petani di Kabupaten Majalengka (Jawa Barat) terhadap PT United Chemical Industry. Serbuan dilakukan karena amarah yang memuncak akibat pencemaran limbah pabrik kimia tersebut atas saluran irigasi yang mengairi lahan pertanian mereka (Aditjondro, 2003:131).

Media ikut memainkan peranan penting dalam mentransformasi problem polusi yang bersifat lokal menjadi isu publik yang lebih luas sebarannya. Pencemaran Kali Brantas di Surabaya oleh PT Miwon dan berbagai tanggapan yang muncul dari masyarakat dan pejabat kota Surabaya, misalnya, telah diangkat dalam berita surat kabar Surabaya Post selama beberapa hari, yakni tanggal 3, 4, 5, dan 7 Juli 1975 (Lucas dan Djati, 2000:102). Demikian pula, majalah Tempo menurunkan berita mengenai pencemaran Kali Surabaya oleh PT Pakabaya, PT Jayabaya, PT Spindo, dan PT Surabaya Wire pabrikpabrik di Kecamatan Driyorejo, dengan judul yang menyentak perhatian, "Surabaya Geger Kepati, Gegernya Air Kena Polusi" (Tempo, 24 September 1977). Sekitar tiga minggu sebelumnya, kasus pencemaran ini telah diekspos Harian Surabaya Post lewat beritanya, "Empat Pabrik lagi Distop" (Surabaya Post, 31 Agustus 1977). Seperti dirujuk dalam tulisan Aditjondro (1979:64), publikasi kasus pencemaran juga dilakukan oleh Majalah Tempo (Maret 1979) dan Harian Merdeka (7 Juni 1979) pada kasus pencemaran yang terkait dengan PT Semarang Diamond Chemical, yang berlokasi di Kecamatan Tugu, Semarang.

Liputan media atas kasus-kasus pencemaran semakin meningkat frekuensinya pada tahun 1980-an dan terlebih lagi pada dekade 1990-an. Liputan media yang semakin meningkat frekuensinya mengenai kasus-kasus pencemaran telah ikut membuka wawasan dan menyadarkan khalayak umum akan isu lingkungan yang mengancam dan harus dicarikan jalan pemecahannya. Kesadaran masyarakat yang meningkat dimanifestasikan antara lain dalam keinginan untuk mengutarakan keluhan, menyampaikan protes, dan bahkan melancarkan demonstrasi terhadap pihak-pihak yang dianggap bertanggung-jawab atas terjadinya pencemaran yang merugikan mereka (Lucas dan djati, 2000:iv). Selain berjasa dalam mempopulerkan isu pencemaran kepa- 
da khalayak luas, media juga berperan penting dalam mengidentifikasi pihakpihak yang terkait dalam kasus pencemaran baik para korban, pelaku pencemaran, maupun pihak terkait lainnya (aparat hukum dan birokrasi pemerintah), besarnya kerugian yang ditimbulkan, serta respons yang muncul terhadap pencemaran.

Peran penting media dalam gerakan memerangi pencemaran juga diakui oleh pemerintah. Pengakuan ini tampak jelas diperlihatkan oleh Pemerintah Daerah Provinsi Jawa Timur dalam "perang" yang dilancarkannya terhadap berbagai industri yang mencemari sungai dengan membuang limbah sembarangan. Wakil Gubernur Jawa Timur, Trimarjono, mengakui media merupakan instrumen penting untuk mengenakan sanksi sosial terhadap pabrik-pabrik yang mencemari lingkungan lewat pemberitaan yang dilakukan (Salim, 2004:92). Dalam inspeksi mendadak (sidak) yang sering dilakukannya ke "pantat" atau bagian belakang pabrik dengan menyusuri aliran sungai, Trimarjono, yang juga sering dijuluki sebagai "Jenderal Limbah", biasanya mengajak awak media baik cetak maupun elektronik untuk melakukan liputan. Dikatakan bahwa pemberitaan yang dilakukan media merupakan senjata ampuh untuk membuat "pengelola pabrik dan industri yang bandel menjadi mati kutu bahkan ketakutan" (Salim, 2004:93).

Sungai menjadi elemen lingkungan yang paling mencolok terkena dampak negatif kegiatan industri. Banyak sungaidi Jawa yang semakin parah tercemar, termasuk pada sungaisungai besarnya seperti Sungai Ciliwung, Sungai Citarum, dan Bengawan Solo (Pare, 2003:20). Kedudukan sungai yang begitu vital bagi kehidupan dan fakta bahwa daerah bantaran sungai sering merupakan area pemukiman penduduk, telah membuat pencemaran sungai dengan cepat berimbas pada penduduk. Pencemaran sungai berkembang menjadi isu yang menyita banyak perhatian. Tidak mengherankan, gerakan anti pencemaran kemudian secara khusus mengambil bentuk gerakan Prokasih (Program Kali Bersih), yang diluncurkan pertama kali pada tahun 1989 (Pare, 2003:20). Di antara berbagai aspek tersebut, termasuk di dalamnya adalah identifikasi sungaisungai yang tercemar dan perusahaanperusahaan yang menjadi sumber atau pelaku pencemaran, serta asistensi dalam pemasangan instalasi pengolah limbah dan monitoring limbah (Lucas dan Djati, 2007:327). Melalui program PROKASIH, pabrik-pabrik yang berlokasai di sekitar sungai diinstruksikan agar mengolah limbahnya terlebih dahulu sebelum dibuang ke sungai sehingga tidak mencemari lingkungan. Jumlah sungai yang dimasukkan dalam PROKASIH meningkat dari 15 sungai pada tahun 1989/1990 menjadi 37 sungai pada tahun 1996/1997 (Pare, 2003:20).

Untuk mengatasi problem sumber pencemaran, sejak tahun 1995 diluncurkan Program Peringkat Kinerja Perusahaan (Proper) dalam rangka menopang Prokasih. Program ini digagas oleh Nabiel Makarim, yang selama 20 tahun bekerja di Badan Pengendalian Dampak Lingkungan (Bapedal). Proper Prokasih dilaksanakan dengan skema "insentif dan dis-insentif" atau "ganjaran dan rasa malu" (Tim Ozon, 2003:17-18). Melalui program ini dilakukan pemeringkatan perusahaanperusahaan berdasarkan kinerja lingkungan oleh Kementerian Lingkungan Hidup dengan memberikan rating dari emas (pada level terbaik), disusul hijau, biru, merah, hingga hitam pada level terburuk. Rating emas diberikan kepada perusahaan-perusahaan yang meme- 
nuhi sejumlah kriteria yang ditetapkan, yakni: memanfaatkan teknologi bersih pencemaran, menghasilkan limbah tanpa bahan pencemar, serta melaksanakan manajemen dampak lingkungan dengan baik (Lucas dan Djati, 2007:327). Pada tahun 1995 sebanyak 187 perusahaan diikutkan dalam kegiatan Proper, meningkat menjadi 270 perusahaan pada tahun 1997 Pada tahun 1995 sebanyak 5 perusahaan memperoleh rating hijau dari 187 perusahaan, meningkat menjadi 14 perusahaan pada tahun 1997 dari 270 perusahaan (Tim Ozon, 2003:17).

Transformasi problem pencemaran menjadi isu politik dan respons atasnya dalam rangka pencarian solusi melalui program konkret merupakan capaian nyata gerakan lingkungan masa kemerdekaan. Capaian-capaian ini memang sempat mendapat apresiasi internasional. Misalnya, Organisasi Lingkungan Amerika (American Society of Environment) memberikan apresiasi untuk aspek manajemen Prokasih. Demikian pula, Proper telah dipuji Bank Dunia dan dijadikan pola acuan oleh sejumlah negara, termasuk Filipina, Mexico, Columbia, China, India, Bangladesh, Thailand, Papua Nugini, dan Venezuela (Pare, 2003:20). Capaiancapaian ini hanyalah sebagian dari perkembangan gerakan lingkungan, di baliknya terdapat proses dinamis yang melibatkan berbagai eksponen pendukung gerakan dalam menggalang kekuatan untuk mencapai target perjuangan. Hal ini dibahas pada bagian berikut

\section{Membangun Kekuatan Gerakan}

Gerakan lingkungan pada masa kemerdekaan ditopang oleh beberapa kelompok sebagai eksponennya. Mereka yang aktif dalam gerakan ling- kungan berasal dari berbagai kalangan dengan latar belakang yang berbeda. Sebagian aktivis gerakan lingkungan datang dari birokrasi pemerintahan. Sebagian aktivis berasal dari kalangan pegawai perusahaan perkebunan swasta. Sebagian aktivis lainnya berlatar belakang pecinta/penggemar alam. Keterlibatan berbagai individu atau kelompok dalam gerakan lingkungan tidak terjadi secara sekaligus, tetapi melalui proses yang berlangsung secara bertahap. Seiring dengan perjalanan waktu, kelompok-kelompok yang tergabung dalam gerakan lingkungan bertambah jumlahnya. Hal ini sejajar dengan semakin meningkatnya kasuskasus lingkungan maupun semakin beraneka-ragamnya persoalan lingkungan yang muncul.

Pada dekade tahun 1950-an gerakan lingkungan di Jawa memperlihatkan peran dominan pemerintah. Eksponen lain khususnya kelompokkelompok non-pemerintah yang berasal dari kalangan masyarakat bisa dikatakan belum memainkan peran yang menonjol dalam gerakan ini. Agensi pemerintah dalam urusan perlindungan lingkungan direpresentasikan secara khusus oleh dua organ birokrasi pemerintah, yakni: (1) Lembaga Perlindungan Alam (LPA), dan (2) Bagian Perlindungan Alam (BPA). Organ pertama berada di bawah naungan Kebun Raya Bogor, sedangkan organ yang kedua berada dalam naungan Jawatan Kehutanan, Kementerian Pertanian dan Urusan Agraria (Setijodiwirijo, 1957:8, Cribb, 1988:7). Beberapa tokoh yang tampil sebagai aktivis dalam gerakan lingkungan, khususnya dalam memperjuangkan perlindungan alam dan satwa liar pada dekade ini, di antaranya adalah A. Hoogerwerf, Koesnoto Setijodiwirijo, dan R. Koesnadi Partosatmoko. Mereka tidak lain adalah ahli-ahli yang bekerja 
dalam lingkaran pemerintahan. A. Hoogerwerf, misalnya, adalah Kepala Bagian Perlindungan Alam dan Perburuan Kebun Raya Bogor. Demikian pula, Koesnoto Setijodiwirijo adalah direktur Kebun Raya Bogor.

Keterlibatan mereka dalam gerakan lingkungan diwujudkan di antaranya melalui tulisan-tulisan yang dipublikasikan dalam berbagai terbitan. Hoogerwerf merupakan tokoh yang paling produktif menyuarakan perhatian terhadap isu lingkungan, bahkan sejak masa kolonial. Di antara tulisannya yang terbit pada tahun 1950-an adalah "Perlindungan Alam dan Pemburuan di Indonesia" yang dimuat dalam Almanak Pertanian 1953 dan Almanak Pertanian 1954. Gagasan Setijodiwirijo dituangkan misalnya dalam tulisan berjudul "Masalah Perlindungan Alam di Indonesia" (Insinjur Indonesia, 4:1718/1957). Sementara itu, setidaknya ada dua artikel yang telah dipublikasikan oleh Partosatmoko, yakni "Arti Perburuan sekarang" (Rimba Indonesia, 2:10 -12/1953) dan "Tugas Perlindungan Alam/Margasatwa Djawatan Kehutanan (Rimba Indonesia, 4:3-5/1955).

Penguatan gerakan lingkungan pada tahun 1950-an dilakukan melalui beberapa upaya. Pertama, secara internasional upaya penguatan ditempuh dengan menjalin kontak dan komunikasi dengan organisasi-organisasi di luar negeri yang menaruh perhatian dan bergerak dalam bidang konservasi lingkungan. Salah satunya adalah secara formal dengan mewakili keanggotaan Indonesia, Lembaga Pusat Penelitian Alam Kebun Raya Bogor bergabung dengan Perserikatan Internasional Untuk Perlindungan Alam dan Sumber Daya Alam (International Union for the Protection of Nature and Natural Resources/IUCN) pada tahun 1954. Komunikasi internasional juga dilakukan dengan Asosiasi Ilmu Penge- tahuan Pasifik (Pacific Science Association), yang berpusat di Hawaii, Amerika Serikat (Basjarudin, 1968:388). Kedua, secara internal penguatan gerakan lingkungan diupayakan melalui pembentukan organisasi pecinta alam. Organisasi semacam ini dilaporkan telah berdiri di empat tempat di Jawa pada tahun 1957, salah satunya adalah Perkumpulan Penggemar Alam yang berpusat di Bogor (Basjarudin, 1971:56). Meskipun perkumpulan ini masih terbatas basis pendukungnya, kelompok ini aktif menyuarakan kemolekan alam tropis dan kekayaannya dalam publikasi majalah "Penggemar Alam" yang perlu dilindungi.

Dominasi peran pemerintah dalam gerakan lingkungan terus berlanjut pada dekade tahun 1960-an. Peran pemerintah direpresentasikan oleh Bagian Perlindungan Alam (BPA), sebagai organ dengan status yang sedikit berbeda karena sejak tahun 1961 LPA telah digabung ke dalamnya. Terbentuknya Departemen Kehutanan pada tahun 1964, sebagai departemen tersendiri, yang terpisah dari Departemen Pertanian dan Urusan Agraria yang sebelumnya menaunginya, menghadirkan sebuah organ birokrasi yang baru untuk menangani perlindungan lingkungan, dengan nama Bagian Pengelolaan Satwa Liar dan Perlindungan Alam (Cribb, 1988:8, Nasution dan Basjarudin, 1968:19-20). Organ birokrasi ini dalam perkembangan selanjutnya digantikan lagi oleh Direktorat Perlindungan dan Pengawetan Alam, menyusul dilikuidasinya Departemen Kehutanan pada tahun 1967 (Basjarudin, 1968:388).

Sejumlah tokoh tampil dalam gerakan perlindungan lingkungan pada dekade tahun 1960-an. Mereka sebagian berasal dari kalangan rimbawan (ahli kehutanan) baik yang berprofesi sebagai akademisi dengan basis perguru- 
an tinggi maupun rimbawan yang mengabdi pada departemen pemerintah. Di antara mereka termasuk Hasan Basjarudin dan T.C. Tarumingkeng. Basjarudin bekerja pada Jawatan Kehutanan pada bidang Planologi Kehutanan, sedangkan Tarumingkeng adalah akademisi dengan keahlian bidang kehutanan dari Institut Pertanian Bogor. Bebe aktivis konservasi berasal dari kalangan pegawai perusahaan perkebunan. Dua nama yang dapat disebut adalah David Hadikesuma, yang menjabat direktur Perkebunan Sukamade Baru dan Lucas Hadiwinoto, Direktur Perkebunan Bande Alit (Hoogerwerf, 1971:11-15 dan Ted, 1974:96).

Untuk memperkuat gerakan lingkungan, pemerintah menetapkan tanggal 17-23 Desember sebagai Pekan Penghijauan Nasional (PPN). Keputusan politis ini diberlakukan sejak tahun 1961 (Tim Presidium, 1997:100), dan menandai perluasan skope penanganan dari upaya yang bersifat lokal, mengarah pada upaya berlingkup nasional. Tanggal 17 ditetapkan sebagai awal pekan penghijauan didasari pertimbangan berupa keyakinan akan kesakralan tanggal ini bagi bangsa Indonesia, yang juga memproklamasikan kemerdekaan pada tanggal 17. Sementara itu, penjatuhan pilihan pada bulan Desember dilandasi pertimbangan klimatologis sebagai musim penghujan di Indonesia sehingga diyakini sebagai waktu yang cocok dan tepat untuk melakukan penanaman pohon karena peluang kesuksesannya lebih besar. Pelaksanaan program PPN memperlihatkan dominasi peran pemerintah.

Sejak ditetapkan pertama kali pada tahun 1961 hingga pelaksanaan pada tahun 1968, program PPN dipusatkan di Jawa. PPN yang pertama diselenggarakan di Gunung Mas Bogor (Jawa Barat), disusul PPN kedua di Gunung Kro-
mong-Palimanan Cirebon (1962). PPN ketiga berlokasi di Kecamatan Putat, Gunung Kidul (1963), PPN keempat di Kecamatan Kademangan, Blitar (1964), PPN kelima absen karena kemelut politik tahun 1965. PPN keenam mengambil lokasi di Galonggong, Wonogiri (1966), PPN ketujuh di Gunung Tidar Banyurejo, Magelang (1967), dan PPN kedelapan berlokasi di Malangbong, Garut (1968) (Tim Presidium, 1997:90). Hal ini mengindikasikan kronisnya masalah lingkungan yang ada di Jawa. Baru pada tahun-tahun berikutnya, pelaksanaan kegiatan PPN dipusatkan di tempat-tempat lain di seluruh Indonesia secara bergantian.

Bukan hanya dalam konteks domestik saja seperti diilustrasikan PPN, kuatnya peran pemerintah dalam gerakan lingkungan juga tampak dalam pengiriman delegasi Indonesia yang dikomandani Emil Salim dalam Konferensi Lingkungan yang diadakan PBB di Stockholm pada 5 Juni 1972 (Aditjondro, 2003:127). Emil Salim pada saat itu tengah menduduki jabatan Menteri Negara Penyempurnaan dan Pembersihan Aparatur Negara dan sekaligus merangkap sebagai Wakil Kepala Bappenas. Peran Emil Salim dan departemen yang dipimpinnya selama beberapa periode mengukuhkan apa yang dalam pandangan Morrison disebut sebagai gerakan lingkungan institusional. Istilah ini dipakai Morrison untuk menunjuk pada kegiatan memperjuangkan perlindungan lingkungan dan pemecahan masalah lingkungan melalui saluran birokrasi dan mendasarkan diri pada klaim pemilikan otoritas formal (Aditjondro, 2003:149).

Memasuki dekade 1970-an, namun demikian, mulai menguat pula adanya kecenderungan baru dalam gerakan lingkungan. Kecenderungan ini ditandai dengan keterlibatan kelompokkelompok di luar birokrasi pemerintah. 
Diantaranya adalah kelompok mahasiswa pecinta alam yang bermunculan di kalangan perguruan tinggi. Dua kelompok mahasiswa pecinta alam yang berada di garda depan adalah Mapala Universitas Indonesia (Mapala UI) di Jakarta dan Kelompok Wanadri yang berlokasi di Bandung (Jawa Barat) (Aditjondro, 2003:127). Mapala UI terbentuk pada tahun 1970 sebagai wadah organisasi-organisasi mahasiswa pencinta alam yang ada di lingkungan Universitas Indonesia. Salah satu di antaranya yang menonjol adalah Mapala Fakultas Sastra UI (Mapala FSUI) yang diresmikan pendiriannya di Bukit Ciampea pada tahun 1964 oleh tokohtokoh aktivis mahasiswa, termasuk di antaranya Soe Hok Gie, Maulana, Koy Gandasuteja, Amin Sumardji, Ratnaesih, dan Edhi Wuryantoro (Wicaksana, 2014:39). Sementara itu, Wanadri, yang secara harafiah berarti gunung di tengah hutan, adalah organisasi yang mewadahi penempuh rimba dan pendaki gunung, yang didirikan oleh mantan para pandu di Bandung pada tanggal 16 Mei 1964. Di antara para tokoh pendiri Wanadri adalah Harry Hardiman, Dani Erwangga dan Astri Suryanto, termasuk pula Iman Taufik, Salahuddin Wahid dan Teddy Shira. Perhimpunan Wanadri menjadi wadah bagi orang-orang yang mencintai kehidupan di alam bebas dengan berbagai elemennya seperti gunung, hutan, sungai, dan perairan (Wanadri, 2014).

Bukan hanya kelompok-kelompok mahasiswa saja, sejak akhir 1970-an sejumlah ilmuwan dari kalangan perguruan tinggi ikut terjun dan terlibat aktif dalam gerakan lingkungan. Keterlibatan mereka menemukan formalisasi terutama dalam wadah pusat studi lingkungan, yang banyak didirikan di berbagai perguruan tinggi sejak tahun 1979. Pembentukannya dikoordinasi Kantor Menteri Negara
Pengawasan Pembangunan dan Lingkungan Hidup, sebuah departemen baru yang dibentuk Presiden Soeharto dan dipimpin oleh Emil Salim. Dalam kururn waktu 15 tahun sejak tahun 1978 hingga 1993, Emil Salim selalu menduduki posisi menteri yang membidangi lingkungan hidup pada tiga kabinet yang dibentuk Soeharto. Ia menduduki posisi sebagai Menteri Negara Urusan Kependudukan dan Lingkungan Hidup dalam Kabinet Pembangunan III periode 1978-1983, sebagai Menteri Negara Pengawasan Pembangunan dan Lingkungan Hidup dalam Kabinet Pembangunan IV dan Kabinet Pembangunan V pada tahun 19831993).

Perkembangan menarik lainnya yang mulai membentuk kecenderungan baru dalam gerakan lingkungan sejak 1970-an keterlibatan kelompokkelompok di luar pemerintah. adalah keterlibatan kelompok seniman melalui karya-karya. Taufik Ismail, seorang penyair kenamaan dari Angkatan 1966, menyuarakan kritik dan keprihatinannya terhadap perusakan hutan dalam salah satu puisi yang dibacakannya di Taman Ismail Marzuki, Jakarta pada tanggal 6 Agustus 1971. Kelompok musisi dari Bandung, Bimbo, ikut berjasa dalam mempopulerisasikan isu-isu lingkungan lewat lagu-lagu yang mereka nyanyikan. Sebagian lagu digubah dari puisi-puisi karya penyair kenamaan, Taufik Ismail yang menyuarakan kecintaan pada alam. Tidak ketinggalan pula, sejumlah fotografer bergabung dalam menyuarakan perlunya kepedulian terhadap lingkungan melalui karya-karya fotografi yang mereka dihasilkan. Bukti-bukti kepedulian para fotografer terhadap lingkungan dipertontonkan kepada publik dengan menggelar eksibisi dan lomba foto bertemakan lingkungan yang digelar di Taman Ismail Marzuki pada 28 
Oktober 1977 (Aditjondro, 2003:127128).

Penyelenggaraan acara tersebut memunculkan inisiatif untuk membentuk sebuah kelompok yang menaruh perhatian pada lingkungan dengan keanggotaan bersifat heterogen. Inisiatif tersebut direalisasikan dengan mengadakan pertemuan yang dimotori Emil Salim, Bedjo Rahardjo, Erna Witoelar, Ir. Rio Rahwartono dan Tjokropranolo, yang melibatkan lebih dari 350 kelompok profesi, hobi, lingkungan, pecinta alam, agama, riset, kampus, jurnalis, dan lembaga-lembaga lainnya. Setelah melalui serangkaian pertemuan, pada tanggal 23 Mei 1978 dideklarasikanlah pembentukan Kelompok Sepuluh Pengembangan Lingkungan Hidup, di Balaikota Jakarta. Kelompok Sepuluh ini terdiri dari Ikatan Arsitek Landsekap Indonesia (IALI), yang diketuai Ir. Zein Rachman, Yayasan Indonesia Hijau (YIH), yang diketuai Dr Fred Hehuwed, Biologi Science Club (BCS) dengan ketua Dedy Darnaedi, Gelanggang Remaja Bulungan, dengan Bedjo Raharjo sebagai ketua, Perhimpunan Burung Indonesia (PBI) yang diketuai H. Kamil Oesman, Perhimpunan Pecinta Tanaman (PPT) di bawah pimpinan Ny. Mudiati Jalil, Grup Wartawan Iptek dibawah pimpinan Soegiarto PS, Kwarnas Gerakan Pramuka oleh Drs. Poernomo, Himpunan Untuk Kelestarian Lingkungan Hidup (HUKLI) oleh George Aditjondro, dan Srutamandala (Sekolah Tinggi Publisistik).

Kepengurusan kelompok ini diisi oleh Ir. Zein Rachman (IALI), yang menduduki posisi ketua, didukung Dedy Darnaedi (BSCc), sebagai Sekretaris I dan Bedjo Rahardjo, sebagai Sekretaris I. Kelompok Sepuluh menjadi wadah kegiatan saling-tukar informasi, gagasan, dan perancangan program bersama menyangkut masalah ling- kungan hidup yang dihadapi demi terwujudnya lingkungan yang lestari. Dalam perkembangannya, beberapa organisasi kemudian ikut bergabung dalam Kelompok Sepuluh. Meskipun demikian, nama Kelompok Sepuluh tetap dipertahankan dengan alasan sebagai bentuk apresiasi historis atas perannya. Organisasi yang ikut di antaranya adalah Yayasan Pendidikan Kelestarian Alam yang dipimpin Ny. Aziz Saleh, Yayasan lembaga Konsumen Indonesia, Persatuan Radio Swasta Niaga Indonesia (PRSSNI), Lembaga Penelitian Pendidikan dan Penerangan Ekonomi dan Sosial (LPES), Ikatan Arsitek Indonesia (IAI), dan Harian Sinar Harapan (Walhi, 2014).

Pembentukan Wahana Lingkungan Hidup Indonesia (Walhi) pada tanggal 15 Oktober 1980 menjadi puncak kecenderungan baru gerakan lingkungan. Walhi dibentuk dalam Pertemuan Nasional Lingkungan Hidup I yang diselenggarakan pada tanggal 13 15 Oktober 1980, yang dibidani Kelompok Sepuluh. Pertemuan ini diikuti 130 orang dari 78 organisasi yang berasal dari tiga kelompok, yaitu organisasi masyarakat (agama, sosial), organisasi pecinta alam, dan organisasi profesi. Beberapa nama yang tampil menonjol dalam pertemuan tersebut adalah George Junus Aditjondro dari Bina Desa, MS Zulkarnaen dari Yayasan Mandiri Bandung, Satjipto Wirosardjono dari PKBI, Rudy Badil dari Mapala UI, dan Zen Rahman dari IAI. Sementara itu, dari kalangan Pusat Studi Lingkungan yang berbasis di perguruan tinggi tampil nama-nama seperti Otto Soemarwoto, Hasan Poerbo, dan Soeratno Partoatmodjo. Pertemuan tersebut mendapat dukungan dari sejumlah kalangan dalam berbagai bentuk baik moral maupun finansial. Dukungan misalnya datang dari Yayasan Pembinaan Suaka Alam dan 
Margasatwa Indonesia/World Wirldife Fund (WWF) yang diketuai oleh Sultan Hamengkubuwono IX. Sejumlah nama tidak ketinggalan pula dalam pemberian dukungan penyelenggaraan pertemuan, di antaranya adalah Purnomo (Menteri Pekerjaan Umum), Soedjarwo (Menteri Kehutanan), selain Emil Salim sebagai Menteri Lingkungan Hidup (Walhi, 2014).

Terbentuknya Walhi menandai munculnya kekuatan baru di luar pemerintah yang patut diperhitungkan dalam mewujudkan lingkungan yang lestari. Pemerintah tidak lagi menjadi pemegang peran dominan satu-satunya dalam arena perlindungan lingkungan dan tidak lagi menjadi motor tunggal dalam gerakan lingkungan. Tampilnya Walhi dalam gerakan lingkungan menandai penguatan secara signifikan gerakan ini khususnya dari sisi keterlibatan kekuatan atau kelompokkelompok di luar pemerintah. Walhi menandai perluasan gerakan lingkungan. Perluasan ini tampak dari komponen penopang gerakan yang semula hanya merupakan apa yang disebut Morrison sebagai gerakan lingkungan institusional yang ditempuh melalui jalur birokrasi resmi menjadi gerakan yang ditopang pula dengan gerakan lingkungan sukarela berbasis organisasi khusus (Aditjondro, 2003:164-165). Seperti halnya mereka yang memperjuangkan lingkungan lewat jalur birokrasi, eksponen gerakan lingkungan di luar pemerintah juga membangun jaringan internasional. WALHI misalnya membangun kerjasama dengan Friends of the Earth (Sahabat Bumi).

Dalam berbagai kasus baik pemerintah maupun Walhi dengan organisasi-organisasi gerakan lingkungan di luar pemerintah yang lain memperlihatkan sifat sinergis dalam memperjuangkan perlindungan lingkungan sehingga memberi kontribusi bagi peng- uatan gerakan lingkungan. Namun demikian, harus diakui pula bahwa dalam kasus-kasus tertentu, Walhi dan organisasi-organisasi pejuang lingkungan lainnya bergerak jauh dan berada pada posisi bergesekan atau bahkan bertabrakan dengan pemerintah. Keadaan demikian terjadi karena penafsiran dan pertimbangan yang tidak sama atas persoalan yang dihadapi. Berbeda dengan organisasi lingkungan yang lebih sering melihat persoalan lingkungan dengan pertimbangan yang lebih spesifik dan terbatas, sepak terjang organ pemerintah khususnya kaum teknokrat yang berada pada jalur birokrasi sering dihadapkan pada situasi dilematis karena harus bergerak dalam batasan-batasan kepentingan pembangunan ekonomi secara makro yang menjadi agenda besar pemerintah Orde Baru. Batasan-batasan tersebut menempatkan mereka pada posisi sulit tatkala harus memutuskan yang lebih diutamakan, kepentingan perlindungan lingkungan atau kepentingan investasi dan ekonomi pada umumnya.

Pilihan-pilihan dilematis yang dihadapi membuat pemerintah sering dikritik sebagai tidak tegas dan tidak konsistem dalam memperjuangkan perlindungan lingkungan. Namun demikian, harus diakui bahwa hingga menjelang berakhirnya kekuasaan Orde baru, gerakan lingkungan telah bertambah kuat dan semakin meluas. Sayangnya, penguatan dan perluasan basis gerakan lingkungan yang telah diraih harus melalui masa turbulensi dari Orde Baru ke Orde Reformasi sehingga sendi-sendi gerakan lingkungan menjadi goyah, sebaliknya pada saat yang sama problem lingkungan bertambah kronis. 


\section{SIMPULAN}

Gerakan lingkungan di Jawa masa kemerdekaan memperlihatkan adanya kesinambungan sejarah dengan masa kolonial. Kesinambungan ini tampak pada tetap dipertahankannya warisan kolonial dalam bentuk kawasan konservasi dan program penghijauan sebagai panasea untuk mengatasi problem lahan kritis dan deforestasi. Penjelasan atas kesinambungan sejarah ini terkait dengan dua faktor. Pertama, isu lingkungan yang menghadang pada masa awal kemerdekaan secara esensial dipandang sama, yakni kerusakan yang mengancam kekayaan hayati baik floristik maupun satwa, serta bahaya erosi dan lahan kritis. Hanya magnitudonya saja yang berbeda. Krisis lingkungan masa kemerdekaan jauh lebih parah akibat perusakan lingkungan yang masif seiring dengan transisi politik pendudukan Jepang dan revolusi kemerdekaan, selain akibat perkembangan demografis yang berlangsung di Jawa menyusul kembalinya situasi normal. Kedua, para aktivis yang bertindak sebagai agens gerakan lingkungan pada awal masa kemerdekaan adalah orang-orang yang sama, yang telah aktif pada bidang perlindungan lingkungan pada masa kolonial. Mereka umumnya adalah orang-orang yang berada di dalam atau dekat dengan lingkaran kekuasaan khususnya organorgan yang bernaung di bawah Departemen Pertanian khususnya yang menangani bidang kehutanan. Dalam perkembangnnya, gerakan lingkungan masa kemerdekaan kemudian melakukan modifikasi untuk meningkatkan efektivitas pengelolaan kawasan konservasi dengan mengadopsi pembentukan taman nasional, maupun dengan adopsi program penyelamatan lingkungan khususnya sumberdaya tanah, air dan hutan melalui program penghijauan yang dilakukan setiap tahun.

Kemunduran kekayaan keanekaragaman hayati, bahaya erosi dan tanah kritis tetap menjadi isu-isu lingkungan yang dominan. Namun, pada tahun 1970-an mulai berkembang isuisu baru dalam gerakan lingkungan. Isu yang terpenting adalah pencemaran. Munculnya isu baru tidak terlepas dari proses industrialisasi yang berlangsung di Jawa sejak pemerintahan Orde Baru. Kehadiran pabrik-pabrik yang beroperasi di sekitar bantaran sungai telah menjadi sumber pencemaran batang air yang mengancam kehidupan. Berbagai kelompok memainkan peranan penting dalam membangkitkan kesadaran akan krisis yang terjadi akibat pencemaran sungai dibangkitkan di Jawa, khususnya aktivis lingkungan yang berasal dari kampus, lembaga nonpemerintah, sejumlah birokrat, dan media massa, serta korban pencemaran. Bukan hanya dalam pembentukan klaim pencemaran sebagai masalah dan mentransformasikannya menjadi isu publik yang perlu solusi politik, kelompok-kelompok ini juga menjadi bagian penting dalam pemecahan masalah pencemaran baik melalui pengidentifikasian sumber masalah maupun dengan mendesakkan dan menngontrol langkah-langkah korektif atas pencemaran dan pelaku pencemaran. Kegiatan Prokasih Proper yang melibatkan sektor industri menjadi bentuk nyata gerakan lingkungan dalam menjawab isu pencemaran.

Munculnya isu baru dan modifikasi gerakan mencerminkan penguatan dan perluasan eksponen gerakan lingkungan. Selama kurang lebih dua dekade pertama masa kemerdekaan, gerakan didominasi oleh kelompok dari jalur birokrasi dan lebih kuat menampilkan sebuah gerakan lingkungan institusional. Seiring dengan perkembangan 
sosio-ekonomi masyarakat, eksponen gerakan mulai menjangkau pula elemen-elemen yang berasal dari luar pemerintah. Kelompok-kelompok yang peduli terhadap penyelamatan lingkungan muncul dari berbagai kalangan, termasuk dari dunia kampus khususnya kelompok mahasiswa pecinta alam dan pusat studi lingkungan, seniman, dan lembaga-lembaga swadaya masyarakat. Perkembangan ini merepresentasikan fenomena terbentuknya gerakan lingkungan sukarela, dengan basis pendukung melintasi batas-batas kelas. Munculnya kelompok-kelompok di luar jalur birokrasi yang direpresentasikan oleh organisasi-organisasi nonpemerintah dan bersifat sukarela sebagai eksponen gerakan lingkungan menandai berakhirnya peran dominan pemerintah, sekaligus menandai dimulainya sebuah era baru yang tengah merekah. Gerakan lingkungan di Jawa mulai beroperasi dengan motor ganda. Dengan dua motor sebagai kekuatan penggerak, kemampuan gerakan lingkungan untuk menyelamatkan lingkungan menjadi lebih besar. Meskipun begitu harus diakui pula muncul tantangan baru bahwa kinerja kedua motor perlu terus disinergikan dan diharmoniskan agar dapat lebih efektif dalam menyelamatkan lingkungan.

\section{DAFTAR PUSTAKA}

Aditjondro, G.Y. 1979. "Industriawan dan Petani Tambak: Kisah Polusi di Dukuh Tapak, Semarang Barat", Pris$m a$, Th. 8, No. 7 (Juli).

Aditjondro, George Junus. 2003. Pola-pola Gerakan Lingkungan. Yogyakarta: Pustaka Pelajar.

Ankersmit, F.R. 1987. Refleksi tentang Sejarah: Pendapat-pendapat Modern tentang Filsafat Sejarah. Jakarta: PT Gramedia.

Basjarudin, Hasan. 1968. "Problems of National Parks and Reserves in Indone- sia and Emerging Countries". IUCN Publication New Series, 10, hlm. 386388.

Basjarudin, Hasan. 1971. "Perlindungan Alam dan Pembinaan Margasatwa Suaka Alam dan Hutan Wisata", Warta Pertanian, 12.

Bloch, March. 1976. The Historian's Craft. Manchester: Manchester UP.

Boomgaard, Peter. 1999. "Oriental Nature, its Friends and its Enemies: Conservation of Nature in Late-Colonial Indonesia", Environment and History, Vol. 5, No. 3.

Cribb, Robert. 1988. "The politics of Environmental Protection in Indonesia", Working Paper No. 48 (Clayton: Centre of Southeast Asian Studies Monash University.

Endert, F.H. 1936. "Lijst van Bestaande Natuurmonumenten en wildreservaaten in Nederlandasch Indie op 1 Mei 1936", dalam Nederlandsch Indische Vereeniging tot Natuurbescherming Verslag over het Jaar 1935.

Fernandes, D. 1946. "Het Boschwezen gedurende de Japansche Bezetting", dalam Economisc Weekblad voor Nederlandsch Indie, Th. 12 No. 8, 4 Mei 1946.

Furnivall, J.S. 1939. Netherlands India: A Study of Plural Economy. Cambridge: Cambridge University Press.

Garner, Robert. 1996. Environmental Politics. London: Prentice Hall.

Gottschalk, Louis. 1986. Mengerti Sejarah. Jakarta: Penerbit UI.

Hannigan, John. 2006. Environmental Sociology. New York: Routledge.

Hoogerwerf, A. 1948. Hoogerwerf, A., "Het Wildreservaat Baloeran", Tectona, 38.

Hoogerwerf, A. 1953. "Perlindungan Alam dan Pemburuan di Indonesia", Almanak Pertanian. Djakarta: Badan Usaha Penerbit Almanak Pertanian.

Hoogerwerf, A. 1954. "Perlindungan Alam dan Pemburuan di Indonesia", Almanak Pertanian. Djakarta: Badan Usaha Penerbit Almanak Pertanian.

Hoogerwerf, A. 1974. Report on a Visit to Wildlife Reserves in East Java, Indonesia, August to November 1971. Austerlitz: Notherlands Commission for Interna- 
tional Nature Protection.

Http:/ / www.walhi.or.id/tentang-kami/ sejarah, "Sejarah Walhi", diakses 4 Agustus 2014.

Http://wanadri.or.id/forum/ showthread.php? "Para Sepuh Wanadri", diakses 4 Agustus 2014.

Kuntowijoyo. 1994. Metodologi Sejarah. Yogyakarta: Tiara Wacana.

Kuntowijoyo. 2008. Penjelasan Sejarah. Yogyakarta: Tiara Wacana.

Lindblad, J. Thomas. 2011. "The Economic Decolonization of Indonesia: a Birds' Eye View", Journal Indonesian and Humanities, Vol. 4.

Lucas, Anton dan Arief W. Jati. 2000. The Dog is Dead so Throw it in the River: Environmental Politics and Water Pollution in Indonesia, An East Java Case Study. Clayton: Monash Asia Institute, 2000.

Lucas, Anton dan Arief W. Jati. 2007. “The Politics of Environmental and Water Pollution in East Jawa", Peter Boomgaard (ed.). A World of Water: Rain, Rivers, and Seas in Southeast Asia. Leiden: KITLV Press.

Mazlish, Bruce. 1966. The Riddle of zhistory: The Great Speculators from Vico to Freud. New York: Harper \& Row.

Nagtegaal, Luc. 1995. “Urban Pollution in Java, 1600-1850”, dalam P.J.M. Nash (ed.), Issues in Urban Development: Case Studies from Indonesia. Leiden; CWNS.

Nasution, Hasan Basjarudin. 1968. “Recent Development in the Field of National Park, Nature Reserve and Natural Areas". Rimba Indonesia, Tahun 13, No. 1-4.

Nawiyanto. 2014. “Gerakan Lingkungan di Jawa Masa Kolonial". Paramita. Vol. 24, No. 1 (Januari).

Pare, Dion. 2003. "Jago Teori Minus Aksi", Ozon, Vol. 4 No. 6 (Maret), hlm. 20.

Partosatmoko, R. Koesnadi. 1953. “Arti Perburuan sekarang", Rimba Indonesia, Tahun 2, No. 10-12 Tahun 1953.

Partosatmoko, R. Koesnadi. 1955. “Tugas Perlindungan Alam/ Margasatwa Djawatan Kehutanan", Rimba Indonesia, Tahun 4, No. 3-5.

Peluso, Nancy Lee. 1992. Rich Forests, Poor
People: Resource Control and Resistance in Java. Berkeley: University of California Press.

Perusahaan Kehutanan. 1969. Perusahaan Kehutanan Negara (Perhutani): Statistik Tahun 1969. Djakarta: Perhutani.

Poerwokoesoemo, Soepardi. 1950. Hutan Reboisasi-Industri. Djakarta: Balai Pustaka.

Poerwokoesoemo, Soepardi. 1954. Hutan Reboisasi Mempertinggi Kemakmuran. Djakarta: Perpustakaan Perguruan Kementeriaan P.P. dan K.

Poerwokoesoemo, Soepardi. 1974. Hutan dan Kehutanan dalam Tiga Jaman, Bagian B. Jakarta: Perum Perhutani.

Ponto, S.A.S. 1954. "Pemakaian dan Pemeliharaan Tanah". Almanak Pertanian 1954. Djakarta: Badan Penerbit Almanak Pertanian.

Salim, Ali. 2004. Trimarjono di Antara Rakyat Jawa Timur. Surabaya: PT Pabrik Kertas Tjiwi Kimia Tbk.

Sardjan, Mohd. 1953. “Kedudukan Pertanian dalam Ekonomi Indonesia dan Kemungkinan2nja". Almanak Pertanian 1953. Djakarta: Badan Penerbit Almanak Pertanian.

Setijodiwirijo, Koesnoto. 1957. "Masalah Perlindungan Alam di Indonesia", Insinjur Indonesia, Tahun 4. No. 17-18.

Singh, Rajendra. 2002. "Teori-Teori Gerakan Sosial Baru", dalam Jurnal Wacana, Vol. 11.

Situmorang, Abdul Wahib. 2013. Dinamika Protes Kolektif Lingkungan Hidup di Indonesia, 1968-2011. Yogyakarta: Pustaka Pelajar.

Soedarma, M.H. 1959a. "Bentjana Alam", Suara Rimbawan. Tahun VII, No. 8 (Agustus), hlm. 44-48.

Soedarma, M.H. 1959b. "Kategori Bentjana Alam", Suara Rimbawan. Tahun VII, No. 9 (September), hlm. 74-80.

Soepardi, R. 1954. Hutan Reboisasi, Mempertinggi Kemakmuran. Jakarta: Perpustakaan Perguruan Kementerian P.P. dan K.

Storey, William Kelleher. 2011. Menulis Sejarah. Yogyakarta: Pustaka Pelajar.

Surabaya Post. 1977. “Empat Pabrik lagi 
Paramita Vol. 25, No. 1 - Januari 2015

Distop", 31 Agustus.

Ted. 1974. "Dimana Engkau Banteng". Gema Perhutani. Special Edition, hlm. 96.

Tempo. 1977. "Surabaya Geger Kepati, Gegernya Air Kena Polusi", 24 September.

Tim Ozon. 2003. "Cacat Proper versi LSM", Vol. 4 No. 6 (Maret).

Tim Ozon. 2003. “Proper Proyek Pemeringkatan?", Majalah Ozon, Vol. 4 No. 6 (Maret).

Tim Presidium. 1997. 35 Tahun Penghijauan di Indonesia. Jakarta: Presidium Kelompok Pelestari Sumber Daya Alam.
Van der Eng, Pierre. 1996. Agricultural Growth in Indonesia: Productivity Change and Policy Impact since 1880. Basingstoke: Macmillan.

Wicaksana, Anom Whani. 2014. Soe Hok Gie Tak Pernah Mati: Catatan tentang Seorang Demonstran. Yogyakarta: Octopus Publishing House.

Zid, Muhammad. 2009. "Menelusuri Pemikiran Habermas tentang Gerakan Lingkungan", Region, Vol. 1. No. 3. 